\title{
Review \\ Growth Hormone and the Auditory Pathway: Neuromodulation and Neuroregeneration
}

\author{
Joaquín Guerra Gómez ${ }^{1, *(1)}$ and Jesús Devesa ${ }^{2, *}$ (i) \\ 1 Otolaryngology, Medical Center Foltra, 15886 Teo, Spain \\ 2 Scientific Direction, Medical Center Foltra, 15886 Teo, Spain \\ * Correspondence: joaquin.guerra.otorrino@gmail.com (J.G.G.); jesus.devesa@usc.es (J.D.); \\ Tel.: +34-981-802-928 (J.G.G. \& J.D.)
}

check for updates

Citation: Gómez, J.G.; Devesa, J. Growth Hormone and the Auditory Pathway: Neuromodulation and Neuroregeneration. Int. J. Mol. Sci. 2021, 22, 2829. https://doi.org/ $10.3390 /$ ijms 22062829

Academic Editor:

Gabriela Pavlinkova

Received: 3 February 2021

Accepted: 5 March 2021

Published: 11 March 2021

Publisher's Note: MDPI stays neutral with regard to jurisdictional claims in published maps and institutional affiliations.

Copyright: (c) 2021 by the authors. Licensee MDPI, Basel, Switzerland. This article is an open access article distributed under the terms and conditions of the Creative Commons Attribution (CC BY) license (https:// creativecommons.org/licenses/by/ $4.0 /)$.
Abstract: Growth hormone (GH) plays an important role in auditory development during the embryonic stage. Exogenous agents such as sound, noise, drugs or trauma, can induce the release of this hormone to perform a protective function and stimulate other mediators that protect the auditory pathway. In addition, GH deficiency conditions hearing loss or central auditory processing disorders. There are promising animal studies that reflect a possible regenerative role when exogenous $\mathrm{GH}$ is used in hearing impairments, demonstrated in in vivo and in vitro studies, and also, even a few studies show beneficial effects in humans presented and substantiated in the main text, although they should not exaggerate the main conclusions.

Keywords: growth hormone; IGF-I; central auditory processing; hearing impairment; hereditary hearing loss; GH deficiency

\section{Introduction}

Hearing begins when the hair cells (HC) located in the cochlea perceive the sound stimulus. This sensory organ transduces the mechanical energy received for its transformation into electrical energy. The auditory pathway is responsible for the transmission of these acoustic signals to the brain, where the information received is processed for conscious perception. This path (afferent) has an opposite path (efferent) from which the received signal is regulated or inhibited. Both routes experience multiple interhemispheric crossings during their trajectory [1]. The physiological process of sound transmission involves the participation of neurotransmitters, in particular glutamate, but also acetylcholine or enkephalins [2] The same occurs with the development and protection of the auditory pathway, processes in which multiple neurotransmitters, hormones, and peptides are also involved, some of which are expressed in the ear itself, as appears to be the case with growth hormone (GH) and its receptor (GHR), at least in chick embryos [3]. This is not surprising, since GH is a pleiotropic hormone expressed at the pituitary level and in a number of cells and tissues where it performs many different functions, far beyond those classically described [4]. Indeed, GH and GHR are widely expressed in the brain, where the hormone and its main mediator Insulin-like Growth Factor-I (IGF-I) play different key roles in fetal and postnatal brain development, maturation, and function [5-7]. Furthermore, GH expression has been detected in neural stem cells [8,9], in which the hormone induces the expression of IGF-I [9].

In addition to the effects of GH/IGF-I on normal brain development and functioning, this system is also involved in the repair processes of the brain after injury, as many studies have already shown good results after GH administration to experimental animals [10-17] and humans [18-27], even when there is no GH deficiency.

Given the significant effects of GH on the brain, it seems logical that this hormone also plays a significant role in the auditory pathway. Even and given that GH secretion 
experiences a continuous decrease from approximately 20 years to being practically undetectable around 60 years of age [4], it is feasible to assume that many of the degenerative processes associated with aging may be related to the deficiency of this hormone; among them could be the hearing loss that is often seen in old age [28,29].

Physiologically, the loss of hair cells (HC) begins in the early stages of life, and they can be clinically observed from the fifth decade of life [28,29]. There are also exogenous factors such as noise, drug toxicity, ischemia or direct trauma that can damage these HC in a reversible or irreversible way, accelerating the process of auditory degeneration. The ability of hair cells to regenerate spontaneously seems not to be possible or really poor in mammals. However, this regeneration has been seen in other animal species, such as birds, reptiles, amphibians and fish [30], after exposure to noise or another ototoxic agent.

In this study we will analyze the role of GH in hearing and the physiological pathways that it regulates, as well as some syndromes related to GH that directly or indirectly condition hearing loss. Finally, we will assess the therapeutic potential of GH in the treatment of auditory pathology.

\section{Physiological Role of GH in the Cochlea and the Auditory Pathway}

Although it had been postulated that GH could be a neurohormone given its cerebral expression [3], most of the GH that exerts its actions at the brain level comes from that secreted by the pituitary gland. Plasma GH easily crosses the blood-brain barrier (BBB) to carry out its actions on neurogenesis, synaptogenesis and myelination, as well as to try to repair brain damage. In the case of IGF-I, although it is also expressed in the brain, its expression depends mainly on GH [4]. As with GH, plasma IGF-I is able to cross the $\mathrm{BBB}$, but only the free fraction of the circulating hormone can do so, therefore its brain concentrations depend on the molar ratio IGF-I/IGFBP3 (its main carrier in plasma). Furthermore, GH induces the expression of several neurotrophic factors that are involved in various regulatory functions of the auditory pathway [31].

Studies in animal models have shown the relevance of GH in the development of the organs of the inner ear. During the embryonic period, the chicks express high GH immune reactivity in the vesicles that will develop the inner ear [3]. During postnatal development in mice, transcriptomic analysis shows an increased level of GH (89) in the cochlear sensory epithelium [32]. Furthermore, during growth and aging, cochlear upregulation of GH (44) occurs along with upregulation of prolactin (108) [33]. GH is a hormone that regulates calcium mineralization and it is also involved in the growth of the temporal bone and the ossicular chain of the middle ear [34]. It is also responsible for the mineralization of otoconia, a calcium carbonate structure located in the vestibular system that informs the cephalic positions, through matrix-related sequences [35]. With respect to the central auditory effects of $\mathrm{GH}$, peripheral administration of its secretagogue GHRH has shown a reduction in late auditory evoked potential latencies in young healthy men, concomitant with an increased circulating GH levels [36].

\section{GH and Hearing Impairment}

Interestingly, hearing is directly related to the growth rate in children and adolescents. In fact, the hearing threshold in infancy can predict growth rate [37]. There are several syndromes with hearing dysfunction in which there is GH deficiency, however this is not a constant for syndromes in which hearing loss exists [38]. That is, depending on the syndrome, there could be an absence or insufficient $\mathrm{GH}$, or a resistance or decreased sensitivity to the hormone. In these cases, there is a deficit of IGF-I, and hearing impairment is mainly related to the decrease in the levels of this GH mediator [37-39].

Adults with untreated, congenital lifetime isolated GH deficiency usually show predominance of mild high-tones sensorineural hearing loss [40]. Neurophysiologic tests show signs of cochlear injury, such as the absence of the stapedial reflex and otoacoustic emissions, also seen in Laron syndrome [41]. The absence of the stapedial reflex implies 
hypersensitivity to noise (hyperacusis) [40-42]. Some syndromic children with impaired GH secretion may have a temporary conductive hearing loss [43].

Both GH deficiency and excess involve an alteration in central auditory processing, leading to cognitive deficits. GH-deficient subjects show an increase of the acoustic P300 latency, whereas in those with acromegaly there is a reduction in the amplitude of this wave, which also conditions cognitive impairment [44]. Brain trauma can also cause a deficit in GH synthesis and secretion. After suffering a head injury, some boxers and kickboxers become GH deficient. In them, the P300 wave amplitudes are lower than in those without GH deficiency [45].

All of the evidence described above demonstrates that GH plays a major role in the entire auditory pathway, corroborating the findings about untreated GH deficient children and hearing loss [42].

\section{The Sound as a Modulator of GH Secretion}

The fact that noise damages the auditory pathway is undoubted, but the mechanisms by which this occurs are not yet well known. The effects of noise on the auditory pathway usually appear rapidly, damaging synapses, inducing the appearance of reactive oxygen species (ROS), calcium accumulation, and recruiting inflammatory mediators (such as IL-6 or TNF) and increasing glutamate excitotoxicity. Noise activates several pathways including caspase or JNK/MAPK dependent and independent pathways [46-48]. Noise also induces cognitive dysfunction that results in the late onset of hippocampal neurogenesis, which develops long after oxidative stress disappeared [49]. This region is more susceptible to noise than the auditory cortex, with greater damage from oxidative stress and oligomerization and hyperphosphorylation of Tau, a microtubule-associated protein [50], which can lead to progressive synaptic loss and neuronal cell death [51,52]. This pathological accumulation of Tau may be correlated with neurodegeneration in the peripheral auditory system [53].

A series of studies showed that prolonged exposure to high intensity noise initially upregulates GH expression [54], increasing its circulating levels, as well as other stress-related hormones, both in humans and in animal models [55,56]. Interestingly, a short but intermittent exposure to a low frequency, moderate intensity sound stimulus increases nerve motility and cellular response, implicating higher circulating GH levels [57]. However, in the long term, these levels are significantly reduced [58]. The decrease in circulating GH is critical in individuals who are growing and maturing, potentially altering their neuronal plasticity and, therefore, affecting their learning and memory [59].

Based on these results, it seems that after exposure to noise, GH can play an important role in neuroprotection and neuroregeneration, at least in animal models, so the next step is to consider whether exogenous GH could exert viable clinical effects to regenerate the auditory pathway.

\section{The Effects of GH: From In Vitro/In Vivo Studies to Clinical Reports}

In vivo and in vitro studies have tried to analyze whether $\mathrm{GH}$ could protect, recover or even regenerate cells involved in hearing. The first studies focused on observing the ability of GH to successfully stimulate the proliferation of cultured outer ear cartilaginous structures (chondrocytes) of rabbits, showing positive results suggesting that GH directly initiates proliferation in rabbit ear chondrocytes and, consequently, in mammals [60].

However, few reports have demonstrated the efficacy of exogenous GH in hearing. In fact, one might even wonder if treatment with this hormone may pose a risk of hearing impairment since, theoretically, the increase in GH induces greater ossification of the ear cavities that could worsen auditory transmission, as apparently seen in acromegaly [61]. However, GH treatment does not increase the risk of hearing loss, either in infants or children or in adults, as has been seen in patients with Turner syndrome and other conditions [62,63] (Table 1). In fact, the incidence of middle ear pathology often decreases with accelerated bone mineralization of the ear cavities in these girls with Turner syndrome [34]. 
Table 1. Selection of hereditary hearing loss syndromes and the involvement of GH on their pathogenesis, associated conditions, or treatment.

\begin{tabular}{|c|c|c|c|c|}
\hline Condition & Findings & Hearing Loss & GH Levels & Benefit with rhGH \\
\hline CHARGE syndrome & $\begin{array}{c}\text { Colobomatous microphthalmia } \\
\text { Congenital heart defects, usually conotruncal } \\
\text { Choanal atresia } \\
\text { Retarded growth and development } \\
\text { Genital hypoplasia, possibly of hypothalamic origin }\end{array}$ & $\begin{array}{c}\text { SNHL } \\
\text { MHL (rare) }\end{array}$ & $\begin{array}{c}\text { Normal } \\
\text { Low (rare) }\end{array}$ & Yes \\
\hline Alström syndrome & $\begin{array}{c}\text { Atypical retinal degeneration with loss of central } \\
\text { vision in infancy } \\
\text { Diabetes mellitus in childhood } \\
\text { Transient obesity } \\
\text { Posterior cortical cataract } \\
\text { Nephropathy } \\
\text { Acanthosis nigricans }\end{array}$ & SNHL & Low & Yes \\
\hline
\end{tabular}

Shortening of the interphalangeal joints of the

hands and feet Intellectual disability

Peculiar facies (short head, small broad upturned

Acrodysostosis

nose with flat nasal bridge and protruding jaw)

Increased bone age

SNHL (rare)

MHL (rare) Normal

Yes

Intrauterine growth retardation

Juvenile arthritis

Short stature

\begin{tabular}{|c|c|c|c|c|}
\hline $\begin{array}{l}\text { Combined growth hormone } \\
\text { deficiency with hearing loss } \\
\text { and limited neck movement }\end{array}$ & $\begin{array}{c}\text { Pituitary hormone deficiencyLimited neck } \\
\text { movement }\end{array}$ & SNHL & Low & Yes \\
\hline Laron syndrome & $\begin{array}{c}\text { Insensitivity to } \mathrm{GH} \text {, usually caused by a mutant } \\
\text { growth hormone receptor } \\
\text { Short stature } \\
\text { Increased sensitivity to insulin }\end{array}$ & $\begin{array}{l}\text { SNHL } \\
\text { MHL (rare) }\end{array}$ & Normal & No \\
\hline $\begin{array}{l}\text { Intrauterine and postnatal } \\
\text { growth failure with } \\
\text { microcephaly and intellectual } \\
\text { disability }\end{array}$ & $\begin{array}{l}\text { Prenatal Growth Failure } \\
\text { Elevated Growth Hormone Levels } \\
\text { Mental Retardation }\end{array}$ & SNHL & Elevated & No \\
\hline Hajduk-Cheney syndrome & $\begin{array}{c}\text { Dissolution of terminal phalanges } \\
\text { Dolichocephaly with occipital prominence } \\
\text { Short stature } \\
\text { Premature loss of teeth }\end{array}$ & $\begin{array}{l}\text { CHL } \\
\text { SNHL }\end{array}$ & $\begin{array}{l}\text { Normal } \\
\text { Low } \\
\text { (sporadic) }\end{array}$ & Yes \\
\hline Richards-Rundle syndrome & $\begin{array}{c}\text { Ataxia } \\
\text { Distal amyotrophy } \\
\text { Intellectual disability } \\
\text { Diabetes mellitus } \\
\text { Absent development of secondary sex } \\
\text { characteristics }\end{array}$ & SNHL & Normal & No \\
\hline EEC syndrome & $\begin{array}{l}\text { Variable ectrodactyly of hands and feet } \\
\text { Absence of lacrimal puncta } \\
\text { Cleft lip-palate } \\
\text { Occasional vestibular abnormalities }\end{array}$ & CHL & $\begin{array}{l}\text { Normal } \\
\text { Low } \\
\text { (sporadic) }\end{array}$ & Yes \\
\hline Crandall syndrome & $\begin{array}{c}\text { Generalized alopecia with pili torti } \\
\text { Growth retardation } \\
\text { Hypogonadism }\end{array}$ & SNHL & Low & Yes \\
\hline $\begin{array}{l}\text { Hypodontia and PEG-shaped } \\
\text { teeth, olivopontocerebellar } \\
\text { dysplasia, hypogonadism and } \\
\text { hearing loss }\end{array}$ & $\begin{array}{c}\text { Olivopontocerebellar degeneration } \\
\text { Hypogonadotropic hypogonadism } \\
\text { Hypodontia } \\
\text { Resistance to GH }\end{array}$ & $\begin{array}{l}\text { SNHL } \\
\text { (unilateral) }\end{array}$ & Normal & No \\
\hline Turner syndrome & $\begin{array}{l}\text { Short stature } \\
\text { Thick or webbed neck } \\
\text { Gonadal dysfunction }\end{array}$ & $\begin{array}{l}\text { CHL } \\
\text { MHL } \\
\text { SNHL }\end{array}$ & Normal & Yes \\
\hline Kabuki syndrome & $\begin{array}{c}\text { Peculiar facial (elongated palpebral fissures and } \\
\text { prominent ears) } \\
\text { Postnatal growth retardation } \\
\text { Intellectual disability } \\
\text { Cardiac anomalies }\end{array}$ & $\begin{array}{l}\text { CHL } \\
\text { MHL } \\
\text { SNHL }\end{array}$ & Normal & Yes \\
\hline
\end{tabular}

SNHL: sensorineural hearing loss; CHL: conductive hearing loss; MHC: mixed hearing loss. Table adapted from Toriello, H et al. Hereditary hearing loss and its syndromes [38]. 
A brain injury, such as traumatic brain injury or cerebral palsy, can lead to a deficit of GH, which implies a replacement treatment with this hormone that, as previously mentioned, is safe and effective in brain repair. In fact, as our group demonstrated, GH treatment is able to restore hearing in patients with cerebral palsy and hearing loss [64]. Its mechanism of action is unknown, but it probably occurs through the regeneration of sensory cochlear cells and the auditory nerve or by accelerating hearing maturity [64]. Furthermore, GH induces the expression of IGF-I, and other neurotrophic factors, which play a relevant role in hearing; circulating levels of IGF-I are directly proportional to the degree of hearing loss in older humans [65]. Moreover, topical administration of IGF-I had been seen to have positive effects on hearing recovery in patients with sudden sensorineural hearing loss [66].

The therapeutic potential of GH for use in other conditions such as ischemia, noiseinduced hearing damage, or drug toxicity needs to be evaluated but appears promising. Early treatment is undoubtedly a factor to ensure its success [64].

\subsection{Hair Cells}

GH administration can stimulate the proliferation of HC after cochlear damage. Zebrafish has been the most studied species of all animal models due to the inherent ability of this fish to induce neuroregeneration. In zebrafish, the use of GH antagonists leads to a significant decrease in cell proliferation in the inner ear. Faced with a stimulus that generates cochlear damage, and damage to hair cells, endogenous GH can increase its expression, to stimulate the regeneration of those auditory hair cells. GH mRNA expression in this case is located perinuclearly around erythrocytes in the blood vessels of the inner ear epithelium. After overexposure to noise, the densities of the saccular hair cells in the GH-treated treated fish were similar to those of the controls, and higher than those of the fish that received buffer. With the use of exogenous GH, cell proliferation was stimulated and apoptosis was reduced in the saccules, lagenae and utricles of the fish treated from the day after acoustic trauma $[54,67]$.

\subsection{Auditory Nerve}

Another study has focused on evaluating the effects on nerve regeneration of neurons of the spiral ganglion, a group of bipolar cell bodies that innervate the ciliated cells of the organ of Corti and project axons to the cochlear nerve. This in vitro study showed that exposure to different concentrations of GH induces branching and cell growth. Regarding an effect of GH on neuronal survival, while it increased after the combined administration of GH and BDNF (Brain Derived Nerve Factor), the administration of only GH failed to reproduce this effect [68].

\subsection{Deep Brain}

The hippocampus is an area of special interest in the auditory pathway since neural circuits connect to this brain structure. Neurons in the hippocampus respond to to action potentials generated in the inner ear following sound stimuli and are not tonotopically organized [69]. During auditory working memory (including coding, maintenance, and retrieval processes), the auditory cortex connects with the hippocampus and the inferior frontal gyrus [70]. This auditory information travels from the auditory cortex to neurons in the median septum and is then projected directly to the hippocampus [69]. Interestingly, studies in rats show that GH is capable of reversing hippocampal dysfunction due to various stress-related conditions, including long-term auditory fear memory [71]. This observation about the effect of GH on excessive fear memory formation has also been reported in the brain amygdala [72]. 


\subsection{Auditory Cortex}

There is a promising prospect for the recovery of auditory processing in GH-deficient patients through the use of GH replacement therapy. Such is the case in patients with Sheehan syndrome. These patients have panhypopituitarism resulting from an infarction of the pituitary gland due to hypovolemic shock or severe hemorrhage. Neurophysiological studies show that the administration of GH decreases the prolongation of P300 latencies after six months of treatment [73]. GH treatment may also improve the frequency of speech in Turner syndrome [74].

\section{Molecular Mechanisms of GH-Dependent Neuroprotection, Synaptogenesis and Neurogenesis}

As mentioned in the Introduction, it is well established that GH gene expression occurs in many tissues and organs, including the central and peripheral nervous system, and this expression is independent of that which occurs in the pituitary gland. GH administration is capable of increasing axonal regeneration, promoting reinnervation, maintaining or inducing Schwann cells proliferation, and reducing muscle atrophy; all this translates into great potential for the treatment of peripheral nerve injuries [75-78]. Since the basis of auditory regeneration seeks molecular targets that allow the development of drugs to restore lost hearing, GH could be one of them.

The neuroprotective and neuroregenerative effects of GH are carried out: 1) by the direct action of this hormone, or 2) by inducing the expression of neurotrophic factors. The direct action of this hormone begins after the binding of GH to its receptor, which leads to the activation of the JAK/STAT signaling pathway, considered as the main intracellular transduction system of the effects of GH, although also the signaling pathways PI3K/Akt, MAPK and Notch are activated by the hormone and play an important role in the effects of this hormone [79-81]. Phosphorylated STATs form dimers that enter the nucleus, where they bind to specific DNA sequences and activate their target genes and other signaling pathways [80]. This activation mechanism has been demonstrated in zebrafish, promoting regeneration of hair cells [82]. In addition, GH has shown to exert anti-inflammatory actions, for example by modifying the immunoreactivity of TNF receptors [83], as well as modifying neuronal excitation and neuroplasticity through up-regulation of the NR2B subunit of the NMDA receptor [71], and it also increases the number of neurons that increase the expression of c-Fos in BLA (basolateral complex amygdala) [72].

As indicated, GH, via STAT5, activates the Notch signaling pathway, which has been shown to be useful in retinal neuroprotection [83]. This effect is clearly demonstrated by the fact that, cotreatment of GH with the Notch signal inhibitor, DAPT, inhibits the neuroprotective effect of the hormone [83]. In the same study, the authors found another neuroprotective effect of $\mathrm{GH}$, exerted via Notch, by the phosphorylation of the PI3K/Akt signaling pathway that reduces the regulation of PTEN, thus decreasing the inflammatory response to kainic acid administration. This study has been carried out in the retina of chicken in which $\mathrm{GH}$ also promotes retinal regeneration after damage induced by kainic acid [83]. Therefore, it does not seem that this could be extrapolated to what happens in the human inner ear, although the retina and inner ear are very specific sensory structures. In fact, in mice, Notch inhibits Atoh1, a relevant factor that plays a major role in the development and regeneration of hair cells [84], however the same study indicates that additional factors are needed for Atoh1 to exert its regenerative effects at the level of certain genes present in HC. Most likely, the type of relationships between Notch and Atoh1 has led to investigate on how to inhibit the target gene Hes5 or $\gamma$-secretase to significantly increase the expression of Atoh1 in the cochlea [85,86].

As indicated above, GH can induce the release of other neurotrophic factors, namely IGF-I and neuropeptides, hormones, neurotrophins, growth factors, and some cytokine signaling suppressors [80]. IGF-I is one of the main regulatory mediators of hearing function. This factor, along with its receptor (IGF-IR), are expressed during cochlear development. IGF-I signaling ensures growth and differentiation of cochlear structures. 
Although the lack of significant amounts of IGF-I alters gene expression in hair cells, partial signaling is sufficient for their normal development [87]. But IGF-I also plays a relevant role in the myelination of the auditory nerve, activating the PI3K/Akt pathway. This promotes differentiation through the expression of myelin core protein and myelinassociated glycoprotein [88]. Therefore, it is likely that some or most of the effects of GH in the inner ear are dependent on GH-induced expression of IGF-I.

It is interesting to note that the neurotrophic effects of $\mathrm{GH}$ are also mediated by the induction of classical neurotrophins such as BDNF and NT3 [12,89], supporting the participation of GH in the recovery of functional synaptic transmission after damage. BDNF and NT-3 are expressed, together with their receptors tyrosine kinase B (TrkB) and tyrosine kinase $C$ (TrkC), respectively, during the embryonic development of the inner ear, and participate in the sensory trophic support of this structure, providing innervation, development and maintenance [90,91]. Erythropoietin (EPO), a hormone also induced by $\mathrm{GH}$, is also expressed in the inner ear, where in vitro studies in cultures of the organ of Corti of rats have shown that it protects hair cells from ischemia [92] or ototoxicity [93], although it lacked positive effects, and even worsened hearing loss, in in vivo studies in these animals after noise-induced damage [94]. Therefore, the effects of EPO at the level of the inner ear still need to be studied in more detail.

Although not directly related to GH, Heregulin (HRG), a member of the epidermal growth factor (EGF) family, has been reported to act as a mitogen. It stimulates the proliferation of utricular macules in mouse cultures, at least during the development of the neonatal inner ear. Its receptors are expressed in the inner ear of newborns and adults in vestibular end organs and Organ of Corti. However, the addition of HRG does not enhace cell proliferation in adults. [95].

\section{Conclusions}

Throughout this review, we see that listening is a complex process that involves multiple factors that act directly or indirectly. It is clear that GH participates in auditory embryonic development and this hormone is released by a sound stimulus or a harmful event. It also plays a role in central auditory processing. Along the same lines, the absence of endogenous GH can lead to hearing loss, while its replacement can help to recover hearing loss, as it has been seen in untreated GH-deficient children. Many children in the world, including Spain, do not receive GH replacement therapy despite that they are GH-deficient. The reasons for it are diverse: Health agencies or GH Committees require two negative GH provocative tests (these are few reliable), a pituitary MRI, and a specific age. Hence, many children suffer GH-deficiency and they are not treated because they do not meet the specified requirements. This is not logical but it is the real thing. We know a number of cases.

We know that multiple etiopathogenic factors cause hearing loss, including genetic and environmental disorders, which are not fully understood. Agents that promote protection from a traumatic event or degenerative process, or ideally regenerate the damage caused, have been investigated for several decades. The apparent irreversibility of hearing loss once the lesion is established forces us to search for molecules that slow down or recover the sensory cells and auditory neurons. Although studies in animal models are recent, their results and those in some GH-deficient children promise to be feasible for treatment with $\mathrm{GH}$, alone or in combination with other factors. In fact, although GH might not have a direct effect, the hormone induces the expression of several factors, mainly IGF-I, which have positive actions on the recovery from hearing loss. In any case, more studies are needed to analyze in detail the effects that GH can have on a damaged cochlea.

Author Contributions: J.G.G. and J.D. contributed equally to writing this manuscript. Both authors have read and agreed to the published version of the manuscript.

Funding: This research received no external funding.

Institutional Review Board Statement: Not applicable. 
Informed Consent Statement: Not applicable.

Data Availability Statement: The data presented in this study are available on request from the corresponding author.

Acknowledgments: To Foundation Foltra (Teo, Spain) for the help given for writing this review.

Conflicts of Interest: The authors declare no conflict of interest.

$\begin{array}{ll}\text { Abbreviations } \\ \text { Akt } & \text { Protein kinase B } \\ \text { BBB } & \text { Blood brain barrier } \\ \text { BDNF } & \text { Brain-derived neurotrophic factor } \\ \text { BLA } & \text { Basolateral complex amygdala } \\ \text { EGF } & \text { Epidermal growth factor } \\ \text { EPO } & \text { Erythropoietin } \\ \text { GH } & \text { Growth hormone } \\ \text { GHR } & \text { Growth hormone receptor } \\ \text { HC } & \text { Hair cell } \\ \text { HRG } & \text { Heregulin } \\ \text { IGF-I } & \text { Insulin-like growth factor-I } \\ \text { IGFBP3 } & \text { Insulin-like growth factor binding protein 3 } \\ \text { IL-6 } & \text { Interleukin.6 } \\ \text { JAK } & \text { Janus kinase } \\ \text { JNK } & \text { c-Jun N-terminal kinase } \\ \text { MAPK } & \text { Mitogen-activated protein kinase } \\ \text { NMDA } & \text { N-Methyl-d-aspartate } \\ \text { NR2B } & \text { Glutamate [NMDA] receptor subunit epsilon-2 } \\ \text { NT-3 } & \text { Neurotrophin-3 } \\ \text { PI3K } & \text { Phosphoinositide 3-kinase } \\ \text { PTEN } & \text { Phosphatase and tensin homolog } \\ \text { Ros } & \text { Reactive oxygen species } \\ \text { STAT } & \text { Signal transducer and activator of transcription } \\ \text { TNF } & \text { Tumor necrosis factor } \\ \text { Trkc } & \text { Tropomyosin receptor kinase C } \\ & \end{array}$

\section{References}

1. Terreros, G.; Delano, P.H. Corticofugal modulation of peripheral auditory responses. Front. Syst. Neurosci. 2015, 9, 134. [CrossRef] [PubMed]

2. Petralia, R.S.; Wenthold, R.J. Neurotransmitters in the auditory system. In Encyclopedia of Neuroscience; Binder, M.D., Hirokawa, H., Windhorst, U., Eds.; Springer: Berlin/Heidelberg, Germany, 2009; pp. 2847-2853.

3. Harvey, S.; Johnson, C.D.; Sanders, E.J. Growth hormone in neural tissues of the chick embryo. J. Endocrinol. 2001, 169, 487-498. [CrossRef]

4. Devesa, J.; Almengló, C.; Devesa, P. Multiple Effects of Growth Hormone in the Body: Is it Really the Hormone for Growth? Clin. Med. Insights Endocrinol. Diabetes 2016, 9, 47-71. [CrossRef] [PubMed]

5. Nyberg, F.; Burman, P. Growth Hormone and Its Receptors in the Central Nervous System—Location and Functional Significance. Horm. Res. 1996, 45, 18-22. [CrossRef] [PubMed]

6. Lobie, P.E.; Zhu, T.; Graichen, R.; Goh, E.L. Growth hormone, insulin-like growth factor I and the CNS: Localization, function and mechanism of action. Growth Horm. IGF Res. 2000, 10 (Suppl. B), S51-S56. [CrossRef]

7. Harvey, S.; Hull, K. Neural Growth Hormone: An Update. J. Mol. Neurosci. 2003, 20, 1-14. [CrossRef]

8. Devesa, J.; Devesa, P.; Reimunde, P.; Arce, V. Growth hormone and kynesitherapy for brain injury recovery. In Brain InjuryPathogenesis, Monitoring, Recovery and Management; Agrawal, A., Ed.; IntechOpen: London, UK, 2012; pp. $417-454$.

9. Pathipati, P.; Gorba, T.; Scheepens, A.; Goffin, V.; Sun, Y.; Fraser, M. Growth hormone and prolactin regulate human neural stem cell regenerative activity. Neuroscience 2011, 190, 409-427. [CrossRef] [PubMed]

10. Devesa, P.; Reimunde, P.; Gallego, R.; Devesa, J.; Arce, V.M. Growth hormone (GH) treatment may cooperate with locally-produced GH in increasing the proliferative response of hippocampal progenitors to kainate-induced injury. Brain Inj. 2011, 25, 503-510. [CrossRef] [PubMed]

11. Li, R.; Guo, S.; Raccurt, M.; Moudilou, E.; Morel, G.; Brittian, K.; Gozal, D. Exogenous growth hormone attenuates cognitive deficits induced by intermittent hypoxia in rats. Neuroscience 2011, 196, 237-250. [CrossRef] 
12. Zhang, H.; Han, M.; Zhang, X.; Sun, X.; Ling, F. The Effect and Mechanism of Growth Hormone Replacement on Cognitive Function in Rats with Traumatic Brain Injury. PLoS ONE 2014, 9, e108518. [CrossRef]

13. Heredia, M.; Fuente, A.; Criado, J.; Yajeya, J.; Devesa, J.; Riolobos, A. Early growth hormone (GH) treatment promotes relevant motor functional improvement after severe frontal cortex lesion in adult rats. Behav. Brain Res. 2013, 247, 48-58. [CrossRef] [PubMed]

14. Heredia, M.; Palomero, J.; De La Fuente, A.; Criado, J.M.; Yajeya, J.; Devesa, J.; Devesa, P.; Vicente-Villardón, J.L.; Riolobos, A.S. Motor Improvement of Skilled Forelimb Use Induced by Treatment with Growth Hormone and Rehabilitation Is Dependent on the Onset of the Treatment after Cortical Ablation. Neural Plast. 2018, 2018, 6125901. [CrossRef]

15. Ong, L.K.; Chow, W.Z.; Tebay, C.; Kluge, M.; Pietrogrande, G.; Zalewska, K.; Crock, P.; Åberg, N.D.; Bivard, A.; Johnson, S.J.; et al. Growth Hormone Improves Cognitive Function After Experimental Stroke. Stroke 2018, 49, 1257-1266. [CrossRef]

16. Heredia, M.; Rodríguez, N.; Robledo, V.S.; Criado, J.M.; De La Fuente, A.; Devesa, J.; Devesa, P.; Riolobos, A.S. Factors Involved in the Functional Motor Recovery of Rats with Cortical Ablation after GH and Rehabilitation Treatment: Cortical Cell Proliferation and Nestin and Actin Expression in the Striatum and Thalamus. Int. J. Mol. Sci. 2019, 20, 5770. [CrossRef] [PubMed]

17. Sanchez-Bezanilla, S.; Åberg, N.D.; Crock, P.; Walker, F.R.; Nilsson, M.; Isgaard, J.; Ong, L.K. Growth Hormone Promotes Motor Function after Experimental Stroke and Enhances Recovery-Promoting Mechanisms within the Peri-Infarct Area. Int. J. Mol. Sci. 2020, 21, 606. [CrossRef] [PubMed]

18. Devesa, J.; Devesa, P.; Reimunde, P. Growth hormone revisited. Med. Clin. 2010, 135, 665-670. [CrossRef] [PubMed]

19. High, W.M., Jr.; Briones-Galang, M.; Clark, J.A.; Gilkison, C.; Mossberg, K.A.; Zgaljardic, D.J.; Masel, B.E.; Urban, R.J. Effect of growth hormone therapy on cognition after traumatic brain injury. J. Neurotrauma 2010, 27, 1565-1575. [CrossRef] [PubMed]

20. Reimunde, P.; Rodicio, C.; López, N.; Alonso, A.; Devesa, P.; Devesa, J. Effects of recombinant growth hormone replacement and physical rehabilitation in recov-ery of gross motor function in children with cerebral palsy. Ther. Clin. Risk Manag. $2010,30,585-592$.

21. Devesa, J.; Alonso, B.; Casteleiro, N.; Couto, P.; Castañón, B.; Zas, E.; Reimunde, P. Effects of recombinant growth hormone (GH) replacement and psychomotor and cognitive stimulation in the neurodevelopment of GH-deficient (GHD) children with cerebral palsy: A pilot study. Ther. Clin. Risk Manag. 2011, 7, 199-206. [CrossRef]

22. Reimunde, P.; Quintana, A.; Castañón, B.; Casteleiro, N.; Vilarnovo, Z.; Otero, A.; Devesa, A.; Otero-Cepeda, X.L.; Devesa, J. Effects of growth hormone $(\mathrm{GH})$ replacement and cognitive rehabilitation in patients with cognitive disorders after traumatic brain injury. Brain Inj. 2011, 25, 65-73. [CrossRef]

23. Devesa, J.; Reimunde, P.; Devesa, P.; Barberá, M.; Arce, V. Growth hormone (GH) and brain trauma. Horm. Behav. 2013, 63, 331-344. [CrossRef]

24. Arce, V.M.; Devesa, P.; Devesa, J. Role of growth hormone (GH) in the treatment on neural diseases: From neuroprotection to neural repair. Neurosci. Res. 2013, 76, 179-186. [CrossRef]

25. Devesa, J.; Díaz-Getino, G.; Rey, P.; García-Cancela, J.; Loures, I.; Nogueiras, S.; De Mendoza, A.H.; Salgado, L.; González, M.; Pablos, T.; et al. Brain Recovery after a Plane Crash: Treatment with Growth Hormone (GH) and Neurorehabilitation: A Case Report. Int. J. Mol. Sci. 2015, 16, 30470-30482. [CrossRef] [PubMed]

26. Mossberg, K.A.; Durham, W.J.; Zgaljardic, D.J.; Gilkison, C.R.; Danesi, C.P.; Sheffield-Moore, M.; Masel, B.E.; Urban, R.J. Functional Changes after Recombinant Human Growth Hormone Replacement in Patients with Chronic Traumatic Brain Injury and Abnormal Growth Hormone Secretion. J. Neurotrauma 2017, 34, 845-852. [CrossRef] [PubMed]

27. Bianchi, V.E.; Locatelli, V.; Rizzi, L. Neurotrophic and Neuroregenerative Effects of GH/IGF1. Int. J. Mol. Sci. 2017, 18, 2441. [CrossRef] [PubMed]

28. Rodríguez Valiente, A.; Trinidad, A.; García Berrocal, J.; Górriz, C.; Ramírez Camacho, R. Extended high-frequency (9-20 kHz) audiometry reference thresholds in 645 healthy subjects. Int. J. Audiol. 2014, 53, 531-545. [CrossRef] [PubMed]

29. Robinson, D.; Sutton, G. Age effect in hearing-A comparative analysis of published threshold data. Int. J. Audiol. 1979, 18, 320-334. [CrossRef]

30. Rubel, E.W.; Furrer, S.A.; Stone, J.S. A brief history of hair cell regeneration research and speculations on the future. Hear. Res. 2013, 297, 42-51. [CrossRef]

31. Guerra, J.; Devesa, J. Hormone Therapy: Challenges for Treating Hearing Impairments. SN Compr. Clin. Med. 2019, 1, 603-615. [CrossRef]

32. Smeti, I.; Assou, S.; Savary, E.; Masmoudi, S.; Zine, A. Transcriptomic Analysis of the Developing and Adult Mouse Cochlear Sensory Epithelia. PLoS ONE 2012, 7, e42987. [CrossRef]

33. Marano, R.J.; Tickner, J.; Redmond, S.L. Prolactin Expression in the Cochlea of Aged BALB/c Mice Is Gender Biased and Correlates to Loss of Bone Mineral Density and Hearing Loss. PLoS ONE 2013, 8, e63952. [CrossRef] [PubMed]

34. Quigley, C.; Crowe, B.; Anglin, D.; Chipman, J. Growth hormone and low dose estrogen in Turner syndrome: Results of a United States multi-center trial to near-final height. J. Clin. Endocrinol. Metab. 2002, 87, 2033-2041. [CrossRef] [PubMed]

35. Shinobu, N.; Mugiya, Y. Effects of Ovine Prolactin, Bovine Growth Hormone and Triiodothyronine on the Calcification of Otoliths and Scales in the Hypophysectomized Goldfish Carassius auratus. Fish. Sci. 1995, 61, 960-963. [CrossRef]

36. Hartmann, A.; Dietl, T.; Krumrey, K.; Vogl, L.; Dirlich, G.; Holsboer, F.; Heuser-Link, M. Changes in late auditory evoked potentials induced by growth hormone-releasing hormone (GHRH) but not somatostatin (SRIF) after peripheral administration in male controls. Peptides 1995, 16, 657-663. [CrossRef] 
37. Welch, D.; Dawes, P.J.D. Childhood Hearing Is Associated with Growth Rates in Infancy and Adolescence. Pediatr. Res. 2007, 62, 495-498. [CrossRef]

38. Toriello, H.; Smith, S. Hereditary Hearing Loss and Its Syndromes, 3rd ed.; Oxford Monographs on Medical Genetics; Oxford University Press: Oxford, UK, 2013.

39. Barrenäs, M.-L.; Landin-Wilhelmsen, K.; Hanson, C. Ear and hearing in relation to genotype and growth in Turner syndrome. Hear. Res. 2000, 144, 21-28. [CrossRef]

40. Prado-Barreto, V.M.; Salvatori, R.; Júnior, R.C.S.; Brandão-Martins, M.B.; Correa, E.A.; Garcez, F.B.; Valença, E.H.O.; Souza, A.H.O.; Pereira, R.M.C.; Nunes, M.A.P.; et al. Hearing Status in Adult Individuals with Lifetime, Untreated Isolated Growth Hormone Deficiency. Otolaryngol. Neck Surg. 2013, 150, 464-471. [CrossRef] [PubMed]

41. Attias, J.; Zarchi, O.; Nageris, B.I.; Laron, Z. Cochlear hearing loss in patients with Laron syndrome. Eur. Arch. Oto-Rhino-Laryngol. 2011, 269, 461-466. [CrossRef]

42. Muus, J.S.; Weir, F.W.; Kreicher, K.L.; Bowlby, D.A.; Discolo, C.M.; Meyer, T.A. Hearing loss in children with growth hormone deficiency. Int. J. Pediatr. Otorhinolaryngol. 2017, 100, 107-113. [CrossRef]

43. Brisset, S.; Slamová, Z.; Dusatkova, P.; Briand-Suleau, A.; Milcent, K.; Metay, C.; Simandlova, M.; Sumnik, Z.; Tosca, L.; Goossens, M.; et al. Anophthalmia, hearing loss, abnormal pituitary development and response to growth hormone therapy in three children with microdeletions of 14q22q23. Mol. Cytogenet. 2014, 7, 17. [CrossRef] [PubMed]

44. Tanriverdi, F.; Yapislar, H.; Karaca, Z.; Unluhizarci, K.; Süer, C.; Kelestimur, F.; Ünlühızarc1, K. Evaluation of cognitive performance by using P300 auditory event related potentials (ERPs) in patients with growth hormone (GH) deficiency and acromegaly. Growth Horm. IGF Res. 2009, 19, 24-30. [CrossRef] [PubMed]

45. Tanriverdi, F.; Suer, C.; Yapışlar, H.; Kocyigit, I.; Selçuklu, A.; Unluhizarci, K.; Casanueva, F.F.; Kelestimur, F. Growth hormone deficiency due to sports-related head trauma is associated with impaired cognitive performance in amateur boxers and kickboxers as revealed by P300 auditory event-related potentials. Clin. Endocrinol. 2013, 78, 730-737. [CrossRef] [PubMed]

46. Wong, A.C.Y.; Ryan, A.F. Mechanisms of sensorineural cell damage, death and survival in the cochlea. Front. Aging Neurosci. 2015, 7, 58. [CrossRef]

47. Waqas, M.; Gao, S.; Ali, M.; Ma, Y.; Li, W. Inner ear hair cell protection in mammals against the noise-induced cochlear damage. Neural Plast. 2018, 2018, 3170801. [CrossRef] [PubMed]

48. Wu, F.; Xiong, H.; Sha, S. Noise-induced loss of sensory hair cells is mediated by ROS/AMPK $\alpha$ pathway. Redox Biol. 2020, $29,101406$. [CrossRef] [PubMed]

49. Liu, L.; Xuan, C.; Shen, P.; He, T.; Chang, Y.; Shi, L.; Tao, S.; Yu, Z.; Brown, R.E.; Wang, J. Hippocampal Mechanisms Underlying Impairment in Spatial Learning Long After Establishment of Noise-Induced Hearing Loss in CBA Mice. Front. Syst. Neurosci. 2018, 12, 35. [CrossRef]

50. Cheng, L.; Wang, S.-H.; Huang, Y.; Liao, X.-M. The hippocampus may be more susceptible to environmental noise than the auditory cortex. Hear. Res. 2016, 333, 93-97. [CrossRef]

51. Stoothoff, W.H.; Johnson, G.V. Tau phosphorylation: Physiological and pathological consequences. Biochim. Biophys. Acta (BBA) Mol. Basis Dis. 2005, 1739, 280-297. [CrossRef] [PubMed]

52. Takashima, A. Tauopathies and Tau Oligomers. J. Alzheimer's Dis. 2013, 37, 565-568. [CrossRef] [PubMed]

53. Du, X.; West, M.; Cai, Q.; Cheng, W.; Ewert, D.; Li, W.; Floyd, R.A.; Kopke, R.D. Antioxidants reduce neurodegeneration and accumulation of pathologic Tau proteins in the auditory system after blast exposure. Free Radic. Biol. Med. 2017, 108, 627-643. [CrossRef] [PubMed]

54. Schuck, J.B.; Sun, H.; Penberthy, W.T.; Cooper, N.G.; Li, X.; E Smith, M. Transcriptomic analysis of the zebrafish inner ear points to growth hormone mediated regeneration following acoustic trauma. BMC Neurosci. 2011, 12, 88. [CrossRef] [PubMed]

55. Favino, A.; Maugeri, U.; Kauchtschischvili, G.; Della Cuna, G.R.; Nappi, G. Radioimmunoassay measurements of serum cortisol, thyroxine, growth hormone and luteinizing hormone with simultaneous electroencephalographic changes during continuous noise in man. J. Nucl. Boil. Med. 1973, 17, 119-122.

56. Armario, A.; Jolin, T. Influence of intensity and duration of exposure to various stressors on serum TSH and GH levels in adult male rats. Life Sci. 1989, 44, 215-221. [CrossRef]

57. Abdulateef, S.; Abdulateef, F.; Majid, A.; Nafea, H. The influence of stimulating the neural response on physiological response in chicks. EPSTEM 2018, 3, 152-158.

58. Armario, A.; Lopez-Calderon, A.; Jolin, T.; Balasch, J. Response of anterior pituitary hormones to chronic stress. The specificity of adaptation. Neurosci. Biobehav. Rev. 1986, 10, 245-250. [CrossRef]

59. Namavar, M.R.; Salehi, M.S.; Tamadon, A.; Bahmani, R.; Shirazi, M.R.J.; Khazali, H.; Dargahi, L.; Pandamooz, S.; MohammadRezazadeh, F.; Rashidi, F.S. The Effects of Acoustic White Noise on the Rat Central Auditory System During the Fetal and Critical Neonatal Periods: A Stereological Study. Noise Heal. 2017, 19, 24-30. [CrossRef] [PubMed]

60. Madsen, K.; Friberg, U.; Roos, P.; Edén, S.; Isaksson, O. Growth hormone stimulates the proliferation of cultured chondrocytes from rabbit ear and rat rib growth cartilage. Nature 1983, 304, 545-547. [CrossRef] [PubMed]

61. Teixeira, L.S.; Silva, I.B.D.O.; Sampaio, A.L.L.; De Oliveira, C.A.P.; Júnior, F.B. Hearing Loss in Acromegaly-A Review. Int. Arch. Otorhinolaryngol. 1990, 22, 313-316. [CrossRef] 
62. Davenport, M.L.; Roush, J.; Liu, C.; Zagar, A.J.; Eugster, E.; Travers, S.; Fechner, P.Y.; Quigley, C.A. Growth Hormone Treatment Does Not Affect Incidences of Middle Ear Disease or Hearing Loss in Infants and Toddlers with Turner Syndrome. Horm. Res. Paediatr. 2010, 74, 23-32. [CrossRef]

63. Ostberg, J.E.; Beckman, A.; Cadge, B.; Conway, G.S. Oestrogen Deficiency and Growth Hormone Treatment in Childhood Are Not Associated with Hearing in Adults with Turner Syndrome. Horm. Res. Paediatr. 2004, 62, 182-186. [CrossRef]

64. Guerra, J.; Devesa, A.; Llorente, D.; Mouro, R.; Alonso, A.; García-Cancela, J.; Devesa, J. Early Treatment with Growth Hormone (GH) and Rehabilitation Recovers Hearing in a Child with Cerebral Palsy. Reports 2019, 2, 4. [CrossRef]

65. La Rosa, L.R.-D.; Lassaletta, L.; Calvino, M.; Murillo-Cuesta, S.; Varela-Nieto, I. The Role of Insulin-Like Growth Factor 1 in the Progression of Age-Related Hearing Loss. Front. Aging Neurosci. 2017, 9, 411. [CrossRef] [PubMed]

66. Nakagawa, T.; Yamamoto, M.; Kumakawa, K.; Usami, S.-I.; Hato, N.; Tabuchi, K.; Takahashi, M.; Fujiwara, K.; Sasaki, A.; Komune, S.; et al. Prognostic impact of salvage treatment on hearing recovery in patients with sudden sensorineural hearing loss refractory to systemic corticosteroids: A retrospective observational study. Auris Nasus Larynx 2016, 43, 489-494. [CrossRef] [PubMed]

67. Sun, H.; Lin, C.-H.; Smith, M.E. Growth Hormone Promotes Hair Cell Regeneration in the Zebrafish (Danio rerio) Inner Ear following Acoustic Trauma. PLoS ONE 2011, 6, e28372. [CrossRef]

68. Gabrielpillai, J.; Geissler, C.; Stock, B.; Stöver, T.; Diensthuber, M. Growth hormone promotes neurite growth of spiral ganglion neurons. NeuroReport 2018, 29, 637-642. [CrossRef] [PubMed]

69. Xiao, C.; Liu, Y.; Xu, J.; Gan, X.; Xiao, Z. Septal and Hippocampal Neurons Contribute to Auditory Relay and Fear Conditioning. Front. Cell. Neurosci. 2018, 12, 102. [CrossRef] [PubMed]

70. Kumar, S.; Joseph, S.; Gander, P.E.; Barascud, N.; Halpern, A.R.; Griffiths, T.D. A Brain System for Auditory Working Memory. J. Neurosci. 2016, 36, 4492-4505. [CrossRef] [PubMed]

71. Weele, C.M.V.; Saenz, C.; Yao, J.; Correia, S.S.; Goosens, K.A. Restoration of hippocampal growth hormone reverses stress-induced hippocampal impairment. Front. Behav. Neurosci. 2013, 7, 66. [CrossRef]

72. Gisabella, B.; Farah, S.; Peng, X.; Burgos-Robles, A.N.; Lim, S.H.; Goosens, K.A. Growth hormone biases amygdala network activation after fear learning. Transl. Psychiatry 2016, 6, e960. [CrossRef]

73. Golgeli, A.; Tanriverdi, F.; Suer, C.; Gokce, C.; Ozesmi, C.; Bayram, F.; Kelestimur, F. Utility of P300 auditory event related potential latency in detecting cognitive dysfunction in growth hormone $(\mathrm{GH})$ deficient patients with Sheehan's syndrome and effects of GH replacement therapy. Eur. J. Endocrinol. 2004, 150, 153-159. [CrossRef]

74. Andersson-Wallgren, G.; Ohlsson, A.-C.; Albertsson-Wikland, K.; Barrenäs, M.-L. Growth Promoting Treatment Normalizes Speech Frequency in Turner Syndrome. Laryngoscope 2008, 118, 1125-1130. [CrossRef] [PubMed]

75. Devesa, P.; Gelabert, M.; Gallego, R.; Relova, J.L.; Devesa, J.; Arce, V.M.; Gonźlez-Mosquera, T. Growth hormone treatment enhances the functional recovery of sciatic nerves after transection and repair. Muscle Nerve 2012, 45, 385-392. [CrossRef]

76. Tuffaha, S.H.; Budihardjo, J.D.; Sarhane, K.A.; Khusheim, M.; Song, D.; Broyles, J.M.; Salvatori, R.; Means, K.R.; Higgins, J.P.; Shores, J.T.; et al. Growth Hormone Therapy Accelerates Axonal Regeneration, Promotes Motor Reinnervation, and Reduces Muscle Atrophy following Peripheral Nerve Injury. Plast. Reconstr. Surg. 2016, 137, 1771-1780. [CrossRef] [PubMed]

77. Devesa, J.; Alonso, A.; López, N.; García, J.; Puell, C.I.; Pablos, T.; Devesa, P. Growth Hormone (GH) and Rehabilitation Promoted Distal Innervation in a Child Affected by Caudal Regression Syndrome. Int. J. Mol. Sci. 2017, 18, 230. [CrossRef] [PubMed]

78. Lopez, J.; Quan, A.; Budihardjo, J.; Xiang, S.; Wang, H.; Koshy, K.; Cashman, C.; Lee, W.P.A.; Hoke, A.; Tuffaha, S.; et al. Growth Hormone Improves Nerve Regeneration, Muscle Re-innervation, and Functional Outcomes After Chronic Denervation Injury. Sci. Rep. 2019, 9, 1-11. [CrossRef]

79. Waters, M.J.; Brooks, A.J. Growth Hormone Receptor: Structure Function Relationships. Horm. Res. Paediatr. 2011, 76, 12-16. [CrossRef] [PubMed]

80. Carter-Su, C.; Schwartz, J.; Argetsinger, L.S. Growth hormone signaling pathways. Growth Horm. IGF Res. 2016, 28, 11-15. [CrossRef]

81. Fleming, T.; Epardo, D.; Balderas-Márquez, J.E.; Carranza, M.; Luna, M.; Harvey, S.; Arámburo, C.; Martínez-Moreno, C.G. GH neuroprotection against kainate (KA) excitotoxicity in the retina is mediated by Notch/PTEN/Akt Signaling. Invest. Ophtalmol. Vis. Sci. 2019, 60, 4532-4547. [CrossRef] [PubMed]

82. Rajadinakaran, G.; Sun, H.; Rinehart, C.; Rouchka, E.; Smith, M. Regulation of cell proliferation and apoptosis by growth hormone during zebrafish auditory hair cell regeneration. BMC Bioinform. 2012, 13, A3. [CrossRef]

83. Martinez-Moreno, C.G.; Epardo, D.; Balderas-Márquez, J.E.; Fleming, T.; Carranza, M.; Luna, M.; Harvey, S.; Arámburo, C. Regenerative Effect of Growth Hormone (GH) in the Retina after Kainic Acid Excitotoxic Damage. Int. J. Mol. Sci. 2019, 20, 4433. [CrossRef]

84. Jen, H.-I.; Hill, M.C.; Tao, L.; Sheng, K.; Cao, W.; Zhang, H.; Yu, H.V.; Llamas, J.; Zong, C.; Martin, J.F.; et al. Transcriptomic and epigenetic regulation of hair cell regeneration in the mouse utricle and its potentiation by Atoh1. eLife 2019, 8, 44328. [CrossRef] [PubMed]

85. Lee, S.; Jeong, H.-S.; Cho, H.-H. Atoh1 as a Coordinator of Sensory Hair Cell Development and Regeneration in the Cochlea. Chonnam Med. J. 2017, 53, 37-46. [CrossRef]

86. Richardson, R.T.; Atkinson, P.J. Atoh1 gene therapy in the cochlea for hair cell regeneration. Expert Opin. Biol. Ther. 2015, 15, 417-430. [CrossRef] [PubMed] 
87. Sanchez-Calderon, H.; La Rosa, L.R.-D.; Milo, M.; Pichel, J.G.; Holley, M.; Varela-Nieto, I. RNA Microarray Analysis in Prenatal Mouse Cochlea Reveals Novel IGF-I Target Genes: Implication of MEF2 and FOXM1 Transcription Factors. PLoS ONE 2010, 5, e8699. [CrossRef] [PubMed]

88. Ogata, T.; Iijima, S.; Hoshikawa, S.; Miura, T.; Yamamoto, S.-I.; Oda, H.; Nakamura, K.; Tanaka, S. Opposing Extracellular Signal-Regulated Kinase and Akt Pathways Control Schwann Cell Myelination. J. Neurosci. 2004, 24, 6724-6732. [CrossRef] [PubMed]

89. Martinez-Moreno, C.; Fleming, T.; Carranza, M.; Ávila-Mendoza, J.; Luna, M.; Harvey, S.; Arámburo, C. Growth hormone protects against kainate excitotoxicity and induces BDNF and NT3 expression in chicken neuroretinal cells. Exp. Eye Res. 2018, 166, 1-12. [CrossRef]

90. Fritzsch, B.; Tessarollo, L.; Coppola, E.; Reichardt, L.F.; Coppola, V. Neurotrophins in the ear: Their roles in sensory neuron survival and fiber guidance. Prog. Brain Res. 2004, 146, 265-278. [CrossRef]

91. Chacko, L.J.; Blumer, M.J.F.; Pechriggl, E.; Rask-Andersen, H.; Dietl, W.; Haim, A.; Fritsch, H.; Glueckert, R.; Dudas, J.; SchrottFischer, A. Role of BDNF and neurotrophic receptors in human inner ear development. Cell Tissue Res. 2017, 370, 347-363. [CrossRef]

92. Naldi, A.M.; Gassmann, M.; Bodmer, D. Erythropoietin but not VEGF has a protective effect on auditory hair cells in the inner ear. Cell. Mol. Life Sci. 2009, 66, 3595-3599. [CrossRef] [PubMed]

93. Monge, A.; Nagy, I.; Bonabi, S.; Schmid, S.; Gassman, M.; Bodmer, D. The effect of erythropoietin on gentamin-induced auditory hair cell loss. Laryngoscope 2006, 116, 312-316. [CrossRef] [PubMed]

94. Frederiksen, B.L.; Cayé-Thomasen, P.; Lund, S.P.; Wagner, N.; Asal, K.; Olsen, N.V.; Thomsena, J. Does erythropoietin augment noise induced hearing loss? Hear. Res. 2007, 223, 129-137. [CrossRef]

95. Hume, C.R.; Kirkegaard, M.; Oesterle, E.C. ErbB Expression: The Mouse Inner Ear and Maturation of the Mitogenic Response to Heregulin. J. Assoc. Res. Otolaryngol. 2003, 4, 422-443. [CrossRef] [PubMed] 